\title{
Effects of Arctium lappa aqueous extract on lipid profile and hepatic enzyme levels of sucrose-induced metabolic syndrome in female rats
}

\author{
Akram Ahangarpour ${ }^{1}$, Fatemeh Ramazani Ali-Akbari ${ }^{2, *}$, Seyyedeh Marjan Mohaghegh ${ }^{3}$, \\ Ebtesam Asadinia ${ }^{3}$
}

\begin{abstract}
${ }^{1}$ Jundishapur University of Medical Sciences, Health Research Institute, Diabetes Research Center, School of Medicine, Department of Physiology, Ahvaz, Iran, ${ }^{2} J u n d i s h a p u r$ University of Medical Sciences, School of Medicine, Departments of

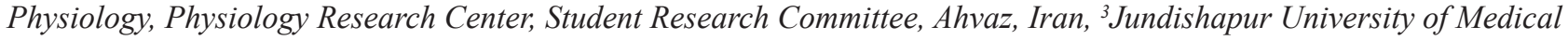
Sciences, School of Para medicine, Department of Nutrition, Student Research Committee, Ahvaz, Iran
\end{abstract}

\begin{abstract}
Arctium lappa is known to have antioxidant and antidiabetic effects in traditional medicine. Objectives: The aim of this paper was to study the effects of A. lappa root extract (AE) on lipid profile and hepatic enzyme levels in sucrose-induced metabolic syndrome (MS) in female rats. The study used 40 adult female Wistar rats weighing $150 \mathrm{~g}-250 \mathrm{~g}$ randomly divided into five groups: control, metabolic syndrome (MS), metabolic syndrome $+\mathrm{AE}$ at $50,100,200 \mathrm{mg} / \mathrm{kg}$. MS was induced by administering $50 \%$ sucrose in drinking water for 6 weeks. AE was intra-peritoneally administered daily at doses of 50,100, and 200 $\mathrm{mg} / \mathrm{kg}$ for two sequential weeks at the end of the fourth week in metabolic syndrome rats. Twenty-four hours after the last administration of AE, blood was collected and centrifuged, and then the serum was used for the measurement of lipid profile and hepatic enzyme. Serum glucose, insulin, fasting insulin resistance index, body weight, water intake, lipid profile, and hepatic enzymes were significantly increased although food intake was decreased in MS rats compared to the control rats. The lipids and liver enzymes were reduced by AE extracts in the MS group. This study showed that the A. lappa root aqueous extract exhibits a hypolipidemic activity of hyperlipidemic rats. This activity is practically that of a triple-impact antioxidant, hypolipidemic, and hepatoprotective.
\end{abstract}

Uniterms: Lappa arctium/effects. Metabolic syndrome. Sucrose/lipid profile/hepatic enzymes.

\section{INTRODUCTION}

Insulin resistance is the main characteristic of the metabolic syndrome (MS), a complex metabolic disorder described by hypertension, obesity, dyslipidemia, hyperinsulinemia, and type 2 diabetes (T2DM). MS is a group of risk factors connected to cardiovascular and chronic liver disorders (Poruba et al., 2015; Flores et al., 2016).

This syndrome has a high prevalence all over the world. Also, both environmental and genetic factors are known to relate to its progression. The recent increase in T2DM and MS is believed to be a consequence of a rise

*Correspondence: F. Ramazani Ali-Akbari. Department of Physiology. Diabetes Research Center, Physiology Research Center Ahvaz. Student Research Committee. Jundishapur University of Medical Sciences. Ahvaz, Iran. E-mail: ramezanizahra66@yahoo.com. in inactive lifestyles combined with access to energy-rich food (Aguilera et al., 2004; Vinagre et al., 2010).

An experimental model that resembles MS can be induced in rats by administering high-fructose or highsucrose (HS) diets.

Sucrose intake, in particular its fructose part induces the insulin resistance status (Aguilera et al., 2004). Fructose is converted into glycerol-3-phosphate, and acetyl-coenzymeA in the liver is used for very low-density lipoprotein (VLDL) production in the liver (Basciano, Federico, Adeli, 2005).

Insulin resistance increases hydrolysis of stored triglycerides in adipocytes and their presence in the blood stream, causing a decrease in plasma levels of HDL-c (Roselino et al., 2012).

The increases liver size and weight; moreover, the fatty liver observed in MS rats could contribute to 
the progression of nonalcoholic steatosis induced by high sugar ingestion, is thought to be connected with obesity, hyperlipidemia, and diabetes (Aguilera et al., 2004).

Previous studies found high plasma concentrations of alanine aminotransferase (ALT) and aspartate aminotransferase (AST), approving hepatic tissue pathology in MS rats (Aguilera et al., 2004).

Herbal drugs utilized for the treatment of these conditions are extracts of plants affluent in antioxidants. Arctium lappa, L. (burdock) belongs to the Asteraceae family is cultivated in many countries, including Japan, and is greatly utilized in traditional medicine as a diuretic, antipyretic, or detoxifying agent (Predes et al., 2009) and also for the treatment of arthritis, hypertension, gout, arteriosclerosis, hepatitis, and tonsillitis.

The main active components separated from burdock are as follows: tannin, arctigenin, arctiin, beta-eudesmol, caffeic acid, chlorogenic acid, inulin, trachelogenin4, sitosterol-beta-D-glucopyranoside, lappaol, and diarctigenin (Chan et al., 2011).

Clinical trial studies show that burdock roots are hepatoprotective and have free radical scavenging effects in relation to the existence of caffeoylquinic acid derivatives (Feng et al., 2012).

Cao et al. assayed the effects of burdock on streptozotocin-induced diabetic rats and realized that burdock's root exhibits hypoglycemic activity (Cao et al., 2012).

Until now, no study has been done on the effects of burdock's root in experimental animals on lipid profiles and hepatic enzymes. Therefore, this study was aimed to assess these parameters in MS rats.

\section{MATERIAL AND METHODS}

\section{Plant and extract}

Burdock root samples were gathered from different places in Iran and then scientifically confirmed by the Botany Department of AJUMS. Voucher specimens of the plant are deposited in the herbarium of the University of Khorassan, (Khorassan, Iran. No. IT-ES/HE 36942). Fresh roots of burdock were cut into small pieces, washed in water, and dried at a temperature not surpassing $40^{\circ} \mathrm{C}$ for a week in an oven )Fante, Dieterish, Rodriguez, 2008). Powder weighing $100 \mathrm{~g}$ was mixed in $200 \mathrm{ml}$ of distilled water and boiled for $30 \mathrm{~min}$. After the mixture was filtered by Whatman paper (No.1), the filtrate was centrifuged at $3500 \mathrm{RMP}$ for $15 \mathrm{~min}$. The supernatant was evaporated at a temperature $40^{\circ} \mathrm{C}$ for $24 \mathrm{~h}$ and the acquired powder $(46.5 \%$ and $46.5 \mathrm{~g}$ of root powder) was maintained at $-20^{\circ} \mathrm{C}$ until utilized (Roghani et al., 2007; Li et al., 2016).

\section{MS experimental model}

A total of 40 adult female Wistar rats, which were normal, healthy, and nearly $150 \mathrm{~g}-250 \mathrm{~g}$ in body weight were purchased from the Physiology Center of Ahvaz. The rats were maintained in plastic cages at $25 \pm 2^{\circ} \mathrm{C}$ with a reverse 12 -hour dark-light cycle and $65 \% \pm 10 \%$ relative moistness. Food and water ad libitum during the study period. Our study was conducted in accordance with the guidelines for ethical laboratory animals' maintenance of the AJUMS, and the investigation protocol was confirmed by the Research Ethics Committee of AJUMS and certificated under the number 88 s113. After a week of adjustment, the rats were divided mainly into two groups, the control group $(n=8)$ that was fed a standard diet and the metabolic syndrome group $(n=32)$ that was fed the standard diet plus $50 \%$ sucrose in drinking water for 6 weeks (Roghani et al., 2007).

Ten days before inducing the metabolic syndrome, every morning between 8 a.m. and 9 a.m., vaginal smears were taken for all groups, and then pro-estrus was a selective phase of this investigation (Santos et al., 2014).. The blood glucose level was measured by a glucometer (Elegans) at the end of the fourth and sixth weeks. MS rats exhibited blood glucose nearly $145 \mathrm{mg} / \mathrm{dl}-150 \mathrm{mg} / \mathrm{dl}$ and insulin resistance regarded to be MS status, and these are the criteria for inclusion into this study (Ahangarpour et al., 2013). The ingestion of food and water and the body weight were monitored during the experiments.

\section{Experimental diet}

After the animals received treatment, during the 6 weeks, their insulin, glucose, lipid profile, and hepatic enzyme levels were measured.

Animals with MS, obtained as depicted above, were divided into four groups $(\mathrm{n}=8)$, the metabolic syndrome group that was fed the standard diet without burdock extract and the metabolic syndrome groups that was fed the standard diet plus burdock extract $(50,100$, $200 \mathrm{mg} / \mathrm{kg}$, IP) (Asgari et al., 2010). The burdock extract was administered daily for two sequential weeks from the end of the fourth week (Asgari et al., 2010). At 24 hours after the end of IP injection, the rats were slightly anesthetized through the use of ether, and blood samples were acquired from the heart (Zamami et al., 2008). The blood was centrifuged at $3500 \mathrm{RMP}$ for $20 \mathrm{~min}$, and then the serum was separated. Serum was stored at $-70^{\circ} \mathrm{C}$ 
until assessment. The serum was utilized to determine the levels of several biochemical factors, including blood glucose, insulin (IRMA kit, DiaSource Belgium, INS), lipid profile, and hepatic enzymes, using commercial kits and enzyme methods (Pars azmoon, Iran). FIRI was computed via the formula: FIRI = fasting insulin $(\mu \mathrm{IU} /$ $\mathrm{ml}) \times$ fasting glucose $(\mathrm{mg} / \mathrm{dl}) / 405$. VLDL equals onefifth of the triglycerides quantity (Ahangarpour et al., 2014).

\section{Statistical Analysis}

The results are presented as mean $\pm \mathrm{SD}$. The data was analyzed via the SPSS program. Comparison between control and MS rats was conducted by t-test, and the difference between the groups was determined by ANOVA and post-hoc LSD tests. The values were regarded as significant when $\mathrm{p}<0.05$.

\section{RESULTS AND DISCUSSION}

Serum glucose, insulin, fasting insulin resistance index, body weight, food intake, water intake, lipid profile, and hepatic enzymes were analyzed by the MS model.

Serum glucose, AST $(\mathrm{p}<0.01)$, insulin, FIRI, TG, total cholesterol, ALP levels, body weight $(\mathrm{p}<0.001)$ and VLDL, water intake $(\mathrm{p}<0.05)$ were significantly increased although HDL $(p<0.01)$, food intake $(p<0.05)$ was decreased in MS rats compared to control rats (Table I).

In this study, increased blood glucose, insulin, insulin resistance, body weight, water intake, TG, total cholesterol, VLDL, hepatic enzymes, and low HDL and food intake, are associated with MS, which agrees with previous studies (Ahangarpour, Yahyavi, 2011; Sampath, Karundevi, 2014). Sucrose administration can increase triglyceride levels via various mechanisms, including the liver's extra production of VLDL-c triglycerides and their release in the bloodstream, decrease the lipoprotein lipase effect and the excretion of triglyceride by feces (Khan et al., 2015, Mousavi et al.; 2012). The increase of blood cholesterol is related to the reduction of endogenous cholesterol absorption or excretion (Khan et al., 2015).

The elevation of plasma glucose and insulin, as well as FIRI, is related to the insulin resistance condition in the HS group. Abundant studies reported that a HS diet induces insulin resistance in animal models (Mousavi et al., 2012).

It has been regarded that insulin resistance and hyperinsulinemia play an important role in the cause of liver disorder. Hypersediment of fat in muscles and adipocytes characterizes insulin resistance with subsequent gathering of fat in the hepatocyte (Lima et al.; 2016), which raises the grade of mitochondrial betaoxidation of fatty acids and ketogenesis that may increase

TABLE I - Serum glucose, insulin, fasting insulin resistance index, body weight, food intake, water intake, lipid profile and hepatic enzymes in metabolic syndrome (MS) model

\begin{tabular}{lccc}
\hline Groups & $\begin{array}{c}\text { Control } \\
\mathbf{n}=\mathbf{8}\end{array}$ & $\mathbf{M S}$ & p-value \\
\hline Glucose(mg/dL) & $101.43 \pm 14.26$ & $140.5 \pm 18.73$ & $\mathrm{a}^{* *}$ \\
Insulin $(\mu \mathrm{IU} / \mathrm{mL})$ & $0.82 \pm 0.44$ & $1.7 \pm 0.89$ & $\mathrm{a}^{* * *}$ \\
FIRI & $3.36 \pm 1.87$ & $9.8 \pm 4.02$ & $\mathrm{a}^{* * *}$ \\
Body weight(g) & $250 \pm 12.3$ & $280 \pm 15.3$ & $\mathrm{a}^{* * *}$ \\
Food intake(g/rat/day) & $25.46 \pm 19.2$ & $19.53 \pm 0.44$ & $\mathrm{a}^{*}$ \\
Water intake(mL/rat/day) & $24.06 \pm 2.4$ & $29.7 \pm 2.5$ & $\mathrm{a}^{*}$ \\
Cholesterol(mg/dL) & $57.83 \pm 4.6$ & $87 \pm 5.63$ & $\mathrm{a}^{* * *}$ \\
TG $(\mathrm{mg} / \mathrm{dL})$ & $67.16 \pm 15.2$ & $102.66 \pm 13.2$ & $\mathrm{a}^{* * *}$ \\
LDL $(\mathrm{mg} / \mathrm{dL})$ & $45.4 \pm 11$ & $43.8 \pm 11$ & $\mathrm{a}^{* *}$ \\
HDL $(\mathrm{mg} / \mathrm{dL})$ & $45.83 \pm 4.6$ & $32.33 \pm 5.37$ & $\mathrm{a}^{*}$ \\
VLDL $(\mathrm{mg} / \mathrm{dL})$ & $13.6 \pm 3$ & $20.53 \pm 2.46$ & $\mathrm{a}^{* *}$ \\
AST(u/l) & $112.42 \pm 8.28$ & $159.85 \pm 21.5$ & \\
ALT(u/l) & $62.42 \pm 3.16$ & $74 \pm 2.63$ & $\mathrm{a}^{* * *}$ \\
ALP(u/l) & $125 \pm 15.14$ & $590.5 \pm 62.52$ & ${ }^{*}$ \\
\hline
\end{tabular}

$\mathrm{a}=$ comparison between control group with MS group. T-test was performed for the differences among two groups. FIRI: Fasting Insulin Resistance Index. $\mathrm{n}=8$; mean $\pm \mathrm{SD}, *=\mathrm{p}<0.05^{* *}=\mathrm{p}<0.01, * * *=\mathrm{p}<0.001$. 
lipid peroxidation and the gathering of reactive oxygen species (ROS) in the liver (Albano, Mottaran, Vidalli, 2005). ROS produce a sort of cellular arousal with a subsequent inflammatory effect that has been known as the pathological agent of liver disorder (Marra et al., 2008).

Reduced insulin sensitivity also participates in lipid metabolism and hyperglycemia. Hypertriglyceridemia was demonstrated to be connected to liver disorder and increased FFA levels, which are responsible for increased insulin levels (Marchesini et al., 2001).

Hyperglycemia in MS is associated with a large ROS generation and critical oxidative damage in various tissues, such as those of the liver. Lipid peroxidation and raised ROS have been identified as factors of decreasing antioxidant defense (Silva et al., 2016). It was demonstrated that the extreme plasma-free fatty acids and glucose levels can be related to insulin resistance (Arner, 2002, Tomas et al., 2002).

\section{Effect of AE on lipid profile}

Intake of Arctium lappa L. root extract was significantly decreased serum total cholesterol, TG $(50,100,200 \mathrm{mg} / \mathrm{kg})$, serum LDL, HDL $(200 \mathrm{mg} / \mathrm{kg})$, VLDL $(100,200 \mathrm{mg} / \mathrm{kg}$ ) levels $(\mathrm{p}<0.001)$, HDL, LDL at $50,100 \mathrm{mg} / \mathrm{kg}(\mathrm{p}<0.01)$ and VLDL at $50 \mathrm{mg} / \mathrm{kg}(\mathrm{p}<0.05)$ compared to MS rats (Table II).

The levels of serum total cholesterol, LDL, HDL, VLDL, and TG returned to the normal range due to AE administration in MS rats.

Surplus adipose tissue secretes various compounds, such as FFAs, adiponectin, and cytokines. Increased FFA levels indicate that increased muscle with fat in the liver is responsible for increased insulin level and insulin resistance. It seems that weight gain leads to insulin resistance.

Hyperinsulinemia can enhance the production of very-low-density lipoprotein and triglycerides. Insulin resistance in muscles leads to glucose intolerance and hyperglycemia, which may be aggravated via enhanced liver gluconeogenesis (Scott et al., 2004).

The hypolipidemic effect of the burdock in the present investigation is in agreement with results on diabetic rats. Previous studies indicated that burdock root extract administration was associated with the improvement of glycogen content in the liver and muscles, lipid metabolism, and blood glucose in diabetic rats (Cao et al., 2012). The hypolipidemic effect of burdock might be related, in part, to its antioxidative activity, which decreases the oxidative stress of hepatocytes, or to other unknown protective mechanism(s), such as the declination in the TG liver and muscle content, fat accumulation, serum insulin, insulin resistance, and glucose.

Burdock includes a wide range of effective pharmacological compounds, such as polyphenolics, phenolic acid, flavonoid, and chlorogenic acid (Faulkner, King, 1976). Chlorogenic acids exhibit hypoglycemic activity besides reducing triglyceride and cholesterol levels (Cao et al., 2012). AE is a flavonoid-abundant extract. Flavonoids exhibiting insulin-like behavior have been separated from the plant. Some sorts of flavonoids can delete the lipid synthesis and release from hepatocytes (Hii et al., 1985). The cholesterol-diminishing activity of burdock is mainly in consequence of the reduction of its absorption in the intestinal tract via lowering pancreatic lipase, elevating lipoprotein lipase activity, and increase

TABLE II - Effect of Arctium lappa L extract on total cholesterol, TG, LDL, HDL and VLDL levels in metabolic syndrome (MS) rats

\begin{tabular}{|c|c|c|c|c|c|c|}
\hline Groups & $\begin{array}{c}\text { Control } \\
n=8\end{array}$ & $\begin{array}{c}\text { MS } \\
\mathrm{n}=\mathbf{8}\end{array}$ & $\begin{array}{c}\text { Extract } \\
(50 \mathrm{mg} / \mathrm{kg}) \\
\mathrm{n}=8\end{array}$ & $\begin{array}{c}\text { Extract } \\
(100 \mathrm{mg} / \mathrm{kg}) \\
\mathrm{n}=8\end{array}$ & $\begin{array}{c}\text { Extract } \\
(200 \mathrm{mg} / \mathrm{k}) \\
\mathrm{n}=\mathbf{8}\end{array}$ & p-value \\
\hline Cholesterol (mg/dL) & $57.83 \pm 4.6$ & $87 \pm 5.63$ & $61.85 \pm 4.37$ & $57.71 \pm 3.23$ & $52.23 \pm 3.99$ & acde*** \\
\hline $\mathrm{TG}(\mathrm{mg} / \mathrm{dL})$ & $67.16 \pm 15.2$ & $102.66 \pm 13.2$ & $73.71 \pm 19.55$ & $65.71 \pm 3.77$ & $60.57 \pm 8.95$ & $\operatorname{acde}^{* * *}$ \\
\hline $\mathrm{LDL}(\mathrm{mg} / \mathrm{dL})$ & $45.4 \pm 11$ & $43.8 \pm 11$ & $37.06 \pm 5.05$ & $35.67 \pm 3.6$ & $22.35 \pm 5.3$ & $\operatorname{cd}^{* *} \mathrm{e}^{* * *}$ \\
\hline HDL (mg/dL) & $45.83 \pm 4.6$ & $32.33 \pm 5.37$ & $47.71 \pm 4.97$ & $52.61 \pm 4.12$ & $64.42 \pm 3.49$ & $\operatorname{acd} * * \mathrm{e}^{* * *}$ \\
\hline VLDL (mg/dL) & $13.6 \pm 3$ & $20.53 \pm 2.46$ & $14.74 \pm 3.91$ & $13.14 \pm 1.75$ & $12.11 \pm 1.79$ & $\mathrm{ac}^{*} \mathrm{de}^{* * *}$ \\
\hline
\end{tabular}

$\mathrm{a}=$ comparison between control group with MS group. $\mathrm{c}=$ comparison between extract at $50 \mathrm{mg} / \mathrm{kg}$ group with MS group. $\mathrm{d}=$ comparison between extract at $100 \mathrm{mg} / \mathrm{kg}$ group with MS group. e = comparison between extract at $200 \mathrm{mg} / \mathrm{kg}$ group with MS group. Triacylglycerol(TG), low density lipoprotein (LDL), high density lipoprotein (HDL), and very low density lipoprotein (VLDL).One-way analysis of variance (ANOVA) and post-hoc least significant difference (LSD) tests were performed for the differences among groups $\mathrm{n}=8$; mean $\pm \mathrm{SD},{ }^{*} \mathrm{p}<0.05, * *=\mathrm{p}<0.01, * * *=\mathrm{p}<0.001$. 
TABLE III - Effect of Arctium lappa L extract on hepatic enzymes in metabolic syndrome (MS) rats

\begin{tabular}{|c|c|c|c|c|c|c|}
\hline Groups & $\begin{array}{c}\text { Control } \\
n=8\end{array}$ & $\begin{array}{c}\text { MS } \\
\mathrm{n}=\mathbf{8}\end{array}$ & $\begin{array}{c}\text { Extract } \\
(50 \mathrm{mg} / \mathrm{kg}) \\
\mathrm{n}=8 \\
\end{array}$ & $\begin{array}{c}\text { Extract } \\
(100 \mathrm{mg} / \mathrm{kg}) \\
n=8 \\
\end{array}$ & $\begin{array}{c}\text { Extract } \\
(200 \mathrm{mg} / \mathrm{kg}) \\
\mathrm{n}=8 \\
\end{array}$ & p-value \\
\hline $\operatorname{AST}(\mathrm{u} / \mathrm{l})$ & $112.42 \pm 8.28$ & $159.85 \pm 21.58$ & $142.85 \pm 7.04$ & $120.83 \pm 9.51$ & $113.16 \pm 7.83$ & $\mathrm{a} * * \mathrm{~b} * \mathrm{e}^{* *}$ \\
\hline $\operatorname{ALT}(\mathrm{u} / \mathrm{l})$ & $62.42 \pm 3.16$ & $74 \pm 2.63$ & $71.28 \pm 6.16$ & $59 \pm 5.71$ & $36 \pm 6.72$ & $\mathrm{de}^{* *}$ \\
\hline $\operatorname{ALP}(\mathrm{u} / 1)$ & $125 \pm 15.14$ & $590.5 \pm 62.52$ & $489.57 \pm 63.21$ & $396.42 \pm 47.2$ & $430.16 \pm 51$ & $\mathrm{a}^{* * *} \mathrm{de}^{* *}$ \\
\hline
\end{tabular}

$\mathrm{a}=$ comparison between control group with MS group. $\mathrm{c}=$ comparison between extract at $50 \mathrm{mg} / \mathrm{kg}$ group with $\mathrm{MS}$ group. $\mathrm{d}=$ comparison between extract at $100 \mathrm{mg} / \mathrm{kg}$ group with MS group. e = comparison between extract at $200 \mathrm{mg} / \mathrm{kg}$ group with MS group. Alanine aminotransferas(ALT), aspartate aminotransferase(AST) and alkaline phosphatase (ALP). One-way analysis of variance $(A N O V A)$ and post-hoc least significant difference $($ LSD) tests were performed for the differences among groups. $\mathrm{n}=8$; mean $\pm \mathrm{SD}, * \mathrm{p}<0.05, * *=\mathrm{p}<0.01, * * *=\mathrm{p}<0.001$.

in liver secretion. Polyphenolics may perform their hypolipidemic activity via the elevation of liver LDL receptors (Samah et al., 2016).

\section{Effect of AE on hepatic enzymes}

Arctium lappa L extract AST, ALT, ALP (100, $200 \mathrm{mg} / \mathrm{kg}$ ) levels $(\mathrm{P}<0.01)$ AST at $50 \mathrm{mg} / \mathrm{kg}(\mathrm{P}<0.05)$ was significantly decreased serum (Table III).

The increase in the level of these enzymes in hyperlipidemic rats depicts an elevation in oxidative agents in consequence of the high plasma lipid level. The results of this study are in agreement with those of various previous investigations that demonstrate elevated plasma lipids, decreased antioxidant defenses, and elevated lipid peroxidation in the liver (Ghosian Moghaddm, Roghani, Maleki, 2016). Our results show that ALT and AST activity in the burdock-administered rats had decreased. The antioxidant effects of burdock have been demonstrated in terms of MDA, CAT, and GSH-Px tests in high-fat-diet rats (Wang et al., 2016).

The hepatoprotective mechanism of burdock might be related, in part, to its antioxidative effect, which reduces the oxidative stress in liver cells. This result is supported via previous studies on the hepatoprotective effect related to reducing fat accumulation, lipid peroxidation, and free radical scavenging effects of the plant (Lin et al., 2002). ALP accumulates in the bile duct and is frequently used to detect the integrity of the liver plasma membrane. Rising total ALP levels in plasma is associated with the elevated osteoplastic effect and described via some level of cholestasis. The present investigation reveals that the ALP level of HS-diet-fed rats were elevated. This increase is caused by de novo synthesis in hepatocytes and a reduction in the biliary release of bile acids and glutathione, which is a credible marker of liver disorder (Zagorova et al., 2015).
Administering burdock caused reduced plasma ALP levels in MS rats. The reduction of the enzyme level is a clear sign of the hepatoprotective effect (Saleh et al., 2015).

Further investigations are needed to recognize the exact molecular mechanisms by which AE improves hepatic enzymes and blood lipids in MS rats.

In conclusion, this study showed that the burdock aqueous extract exhibits hypolipidemic activity in hyperlipidemic rats. This activity is practically that of a triple-impact antioxidant, hypolipidemic, and hepatoprotective. The burdock can defend cells from fat accumulation and oxidative stress. These effects are clearly derived from its high levels of flavonoids and polyphenolics.

\section{ACKNOWLEDGEMENTS}

We would like to thank the Departments of Physiology, Jundishapur Medical Sciences University of Ahvaz. This study financially supported by vice chancellor of research affairs of the Ahvaz Jundishapur University of Medical Sciences (Grant No.88S113).

\section{REFERENCES}

AGUILERA, A.A.; DIAZ, G.H.; BARCELATA, M.L.; GUERRERO, O.A.; ROS, R.M. Effects of fish oil on hypertension, plasma lipids, and tumor necrosis factor-alpha in rats with sucrose-induced metabolic syndrome. J. Nutr. Biochem., v.15, n.6, p. 350-357, 2004.

AHANGARPOUR, A.; MOHAGHAGHEGH, M.; ASADINIA, E.; RAMAZANI ALI-AKBARI, F. Effect of Arctium lappa root extract on glucose levels and insulin resistance in rats with high sucrose diet. J. Shahid Sadoughi Univ. Med. Sci., v. 21, n. 2 , p. $179-88,2013$. 
AHANGARPOUR, A., HEIDARI, H., RAMAZANI ALIAKBARI, F., PAKMEHR, M., SHABBAZIAN, H., AHMAD, I. Effect of Boswellia serrata supplementation on blood lipid, hepatic enzymes and fructosamine levels in type2 diabetic patients. J. Diabetes Metab. Disord., v. 13, n.1, p.1-29, 2014.

AHANGARPOUR, A., YAHYAVI, H. Effect of Cyperus rotundus rhizomes on blood glucose, lipid, insulin and hepatic enzyme in insulin resistance model of male rats. Qom Univ. Med. Sci. J., v.5, n.2, p.5-70, 2011.

ALBANO, E.; MOTTARAN, E.; VIDALI, M. Immune response towards lipid peroxidation products as a predictor of progression of non-alcoholic fatty liver disease to advanced fibrosis. Gut., v.54, n.7, p.987-993, 2005.

ARNER, P. Insulin resistance in type 2 diabetes: role of fatty acid. Metab. Res. Rev., v.18, p.5-9, 2002.

ASGARI, S.; RAHIMI, P.; MAHZOUNI, P.; KABIRI, N. Hypoglycemic effect of extract of Juglans regia L.leaves on alloxan induced diabetic rats. Int. J. Med. Arom. Plants, v. 26, n. 47, p. 30-39, 2010.

BASCIANO, H.; FEDERICO, L.; ADELI K. Fructose, insulin resistance, and metabolic dyslipidemia. Nutr. Metab. (Lond), v.2, n.1, p.1-5, 2005.

CAO, J.; LI, C.; ZHANG, P.; CAO, X.; HUANG, T.; BAI, Y.; CHEN, K. Antidiabetic effect of burdock (Arctium lappa L.) root ethanolic extract on streptozotocin-induced diabetic rats. Afr. J. Biotechnol., v.11, n.37, p.9079-9085, 2012.

CHAN, Y.Sh.; CHENG, L.N.; WU, J.H.; CHAN, E.; KWAN, Y.W.; LEE, S.M.; LEUNG, G.P.; YU, P.H.; CHAN, S.W. A review of the pharmacological effects of Arctium lappa (burdock). Inflammopharmacology, v.19, p.245-254, 2011. CHECK THE REFERENCE

FANTE, CA.; DIETERISH, S.; RODRIGUEZ, R. Betamethasone and aqueous extract of Arctium lappa for treating angiostrongyliasis. Rev. Soc. Bras. Med. Trop., v.41, n.6, p.654-7, 2008.

FAULKNER, W.R.; KING, J.W. Renal function. In: TEITZ, N. (Ed). Fundamentals of clinical chemistry. Philadelphia: W.B. Saunders, 1976. p.975-1014.
FENG, C.J.; PENG YING, Z.; CHENG WEI, S.; TAO TAO, H.; YUN GUI, B.; KAO SHAN, C. Effect of aqueous extract of Arctium lappa L. (burdock) roots on the sexual behavior of male rats. BMC. Complement. Altern. Med., v.1, n.12, p.12-18, 2012.

GHOSIAN MOGHADDM, M.H.; ROGHANI, M.; MALEKI, M. Effect of Hypericum perforatum aqueous extracts on serum lipids, aminotransferases, and lipid peroxidation in hyperlipidemic rats. Res. Cardiovasc. Med., v.5, n.2, p.1-6, 2016.

HII, C.S.; HOWELL, S.L. Effect of flavonoids on insulin secretion and $45 \mathrm{Ca}+2$ handling in rat islets of Langerhans. J. Endocrin., v.107, p.1-8, 1985.

KHAN, N.; AKHTAR, M.S.; KHAN, B.A.; BRAGA, V., REICH, A. Antiobesity, hypolipidemic, antioxidant and hepatoprotective effects of Achyranthes aspera seed saponins in high cholesterol fed albino rats. Arch. Med. Sci., v.11, n.6, p.1261-71, 2015.

LI, K.; YU, Y.; SUN, S.; LIU, Y.; GARG, S.; KAUL, S.C.; LEI, Z.; GAO, R.; WADHWA, R.; ZHANG, Z. Functional characterisation of anticancer activity in the aqueous extract of Helicteres angustifolia L. roots. PLoS One, v.11, n.3, p.1-17, 2016.

LIMA, M.; LEITE, L.; GIODA, C.; LEME, F.; COUTO, C.; COIMBRA, C.; LEITE,V.; CRISTINA, T.; FERRARI A. A novel wistar rat model of obesity-related nonalcoholic fatty liver disease induced by sucrose-rich diet. J. Diabetes Res., v.2016, p.1-16, 2016.

LIN, S.C.; LIN, C.H.; LIN, C.C.; LIN, Y.H.; CHEN, C.F.; CHEN, I.C.; WANG, L.Y. Hepatoprotective effects of Arctium lappa Linne on liver injuries induced by chronic ethanol consumption and potentiated by carbon tetrachloride. J. Biomed. Sci., v. 9, n.5, p.401-9, 2002.

MARCHESINI, G.; BRIZI, M.; BIANCHI, G.; TOMASSETTI, S.; BUGIANESI, E.; LENZI, M.; CULlOUGH, A.; NATALE, S.; FORLANI, G.; MELCHIONDA, N. Nonalcoholic fatty liver disease, a feature of the metabolic syndrome. Diabetes, v.50, p.1844-1850, 2001.

MARRA, F.; GASTALDELLI, A.; SVEGLIATI BARONI, G.; TELL, G.; TIRIBELLI, C. Molecular basis and mechanisms of progression of non-alcoholic steatohepatitis. Trends Mol. Med., v.14, n.2, p.72-81, 2008. 
MOUSAVI, S.E.; SHAHRIARIB, A.; AHAGARPOUR, A.; VATANPOUR, H.; JOLODARE, A. Effects of Teucrium polium ethyl acetate extract on serum, liver and muscle triglyceride content of sucrose-induced insulin resistance in rat. IJPR., v.11, n.1, p.347-355, 2012.

FLORES, Y.N;AUSLANDER,A.; CRESP, C.M.; RODRIGUEZ, M.; ZHANG, Z.F.; DURAZO, F.; SALMERON, J. Longitudinal association of obesity, metabolic syndrome and diabetes with risk of elevated aminotransferase levels in a cohort of Mexican health workers. J. Dig. Dis., v.17, n.5, p.1304-12, 2016.

PORUBA M, Z.; MATUŠKOVÁ, L.; KAZDOVÁ, O.; OLIYARNYK, H.; MALÍNSKÁ, I.; TOZZI DI ANGELO, R. Positive effects of different drug forms of silybin in the treatment of metabolic syndrome. Physiol. Res., v.64, Suppl. 4, p.S507-S512, 2015.

PREDES, F.; MATTA, S.; MOMTEIRO, J.; OLIVIERA, T. Investigation of liver tissue and biochemical parameters of adult wistar rats treated with Arctium lappa L. Braz. Arch. Biol. Technol., v.52, n.2, p.335-340, 2009.

ROGHANI, M.; BALUCHNEJADMOJARAD, T.; AMIN, A.; AMIRTOURI, R. The effect of administration of Apium graveolens aqueous extract on the serum levels of glucose and lipids of diabetic rats. Int. J. Emerg. Med., v.9, n.2, p.177-181, 2007.

ROSELINO, M.N.; PAULY-SILVEIRA, N.D.; CAVALLINI, D.C.; CELIBERTO, L.S.; PINTO, R.A.;VENDRAMINI, R.C., ROSSI, E.A. A potential synbiotic product improves the lipid profile of diabetic rats. Lipids Health Dis., v.11, p.114-123, 2012.

SALEH, H.; SOLIMAN, A.M.; MOHAMED, A.S.; MARIE, M.A. Antioxidant effect of sepia ink extract on extrahepatic cholestasis induced by bile duct ligation in rats. Biomed. Environ. Sci., v.28, n.8, p.582-94, 2015.

SAMAH, A.; NEWARY, E.; SULIEMAN, S.; ATTAR, E.; SITOHY, M. Hypolipidemic and antioxidant activity of the aqueous extract from the uneaten pulp of the fruit from Cordia dichotoma in healthy and hyperlipidemic Wistar albino rats. J. Nat. Med., v.70, n.3, p.539-53, 2016.

SAMPATH, S., KARUNDEVI, B. Effect of troxerutin on insulin signaling molecules in the gastrocnemius muscle of high fat and sucrose-induced type-2 diabetic adult male rat. Mol. Cell. Biochem., v.393, n.551, p.2102-2107, 2014.
SANTOS, R.O.; ASSUNCAO, G.L.; MEDEIRROS, D.M.; SOUSA PINTO, I.A.; BARROS, K.S.; SOARES, B.L.; ANDRE, E.; GAVIOLI, E.C.; PAULA SOARESRACHETTI, V. Evaluation of the effect of acute sibutramine in female rats in the elevated T-maze and elevated plus-maze tests. Basic. Clin. Pharmacol. Toxicol., v.114, n.2, p.181187, 2014.

SCOTT, M.; GRUNDY, H.; BRYAN, B.; JAMES, I.;SINDNEY, C.; SMITH, J.; CLAUDEl, L. Definition of metabolic syndrome. Circulation, v.109, p.433-438, 2004.

SILVA, A.R.; CERDEIRA, C.D.; BRITO, A.R.; SALLES, B.C.; RAVAZI, G.F.; MORAES, G.O.; RUFINO, L.R.; OLIVEIRA, R.B.; SANTOS, G.B. Green banana pasta diet prevents oxidative damage in liver and kidney and improves biochemical parameters in type 1 diabetic rats. Arch. Endocrinol. Metab., v.60, n.4, p.355-360, 2016.

TOMAS, E.; LIN, Y.S.; DAGHER, Z.; SAHA, A.; LUO, Z.; IDO, Y.; RUDERMAN, N.B. Hyperglycemia and insulin resistance: possible mechanisms. Ann. NY Acad. Sci., v.967, p. 43-51, 2002.

WANG, Z.; LI, P.; WANG, C.; JIANG, Q.; ZHANG, L.; CAO,Y.; ZHONG, W. Protective effects of Arctium lappa L. root extracts (AREs) on high fat diet induced quail atherosclerosis. BMC Complement. Altern. Med., v.16, p.1-11, 2016.

VINAGRE, A.S.; RONNAU, Â.; PEREIRA, S.F.; SILVEIRA, L.U.; WIILLAND, E.F.; SUYENAGA, E.S. Anti-diabetic effects of Campomanesia xanthocarpa (Berg) leaf decoction. Braz. J. Pharm. Sci., v.46, n.2, p.170-177, 2010.

ZAGOROVA, M.; PRASNICKA, A.; KADOVA, Z.; DOLEZELOVA, E.; KAZDOVA, L.; CERMANOVA, J.; ROZKYDALOVA, L.; HROCH, M.; MOKRY, J.; MICUDA, S. Boldine attenuates cholestasis associated with nonalcoholic fatty liver disease in hereditary hypertriglyceridemic rats fed by high-sucrose diet. Physiol. Res., v.64, n.????, p.467-476, 2015.

ZAMAMI, Y., TAKATORI, S., GODA, M., KOYAMA, T., IWATANI, Y., JIN, X. Royal jelly ameliorates insulin resistance in fructose-drinking rats. Biol. Pharm. Bull., v.31, n.11, p.2103-7, 2008.

Received for publication on $28^{\text {th }}$ July 2015 Accepted for publication on $15^{\text {th }}$ August 2016 
